\title{
Peningkatan Pemahaman Masyarakat terkait Kelahiran Bayi dan Kependudukan di Kelurahan Tamalanrea Jaya Kecamatan Tamalanrea Kota Makassar
}

\author{
Ansari Saleh Ahmar', M. Nadjib Bustan ${ }^{1}$, \& Ramli Umar²
}

\begin{tabular}{ll}
\hline Keywords : & Abstrak. Masalah surveilans atau pemantuan kesehatan ibu \\
Pemahaman Masyarakat; & dan anak (KIA) masih ditandai dengan belum terlapor dan \\
Kelahiran Bayi; Kependudukan. & tercatat dengan sempurna, sepenuhnya dan tepat waktu \\
& semua peristiwa kehamilan dan persalinan di wilayah kerja \\
Corespondensi Author & bidan kelurahan. Sasaran surveilans ditujukan kepada \\
'Program Studi Statistika, Fakultas & seluruh peristiwa kelahiran bayi dari seluruh kehamilan \\
Matematika dan Ilmu Pengetahuan & yang tercatat. Sehingga metode dan/atau strategi yang \\
Alam, Universitas Negeri Makassar & dilakukan untuk mencapai kondisi yang diharapkan yaitu \\
& Surveilans dan Community development. Hasil: (1) \\
'Program Geografi, Fakultas & meningkatnya partisipasi masyarakat dalam melaporkan \\
Matematika dan Ilmu Pengetahuan & diri ketika hamil dan updating data kependudukan; (2) \\
Alam, Universitas Negeri Makassar & meningkatnya pengetahuan dan keterampilan masyarakat \\
Email: ansarisaleh@unm.ac.id & mengenai kelahiran bayi, ibu hamil, dan kependudukan.
\end{tabular}

\section{History Artikel}

Received: Agustus 2019

Reviewed: Agustus 2019

Revised: Agustus 2019

Accepted: Oktober 2019

Published: Oktober 2019

This work is licensed under a Creative Commons Attribution

4.0 International License

\section{Pendahuluan}

Di setiap kelurahan di seluruh wilayah kecamatan tersedia bidan kelurahan yang memberikan layanan kehamilan dan persalinan kepada ibu hamil melalui organisasi kelas Ibu Hamil dan Posyandu/Polindes. Selain itu akan dilakukan kerja sama dengan masyarakat melalui lembaga pemberdayaan masyarakat (LPM) di setiap kelurahan yang mengkordinir seluruh kegiatan partisipatif masyarakat dalam pembangunan.

Setiap ibu hamil diharapkan melakukan kunjungan antenatal ke Puskesmas/Posyandu/Bidan untuk memeriksa kesehatan kehamilannya. Selanjutnya, persalinan yang terjadi diharapkan semuanya ditolong oleh bidan dan tenaga kesehatan trampil di Puskesmas atau fasilitas kesehatan lainnya. Masalahnya, angka pertolongan persalinan di Kecamatan Tamalanrea ini masih rendah, sebesar 55\%. Setiap persalinan ibu atau kelahiran bayi baru seharusnya dicatat, dilaporkan dan diberikan surat keterangan lahir. Proporsi Kelahiran yang mendapat surat keterangan lahir inipun masih rendah, mencakup hanya $45 \%$.

Masalah surveilans atau pemantuan kesehatan ibu dan anak (KIA) masih ditandai 
Ansari Saleh Ahmar, M.Nadjib Bustan, Ramli Umar. Peningkatan Pemahaman Masyarakat terkait Kelahiran Bayi dan Kependudukan di Kelurahan Tamalanrea Jaya Kecamatan

Tamalanrea Kota Makassar

dengan belum terlapor dan tercatat dengan sempurna, sepenuhnya dan tepat waktu semua peristiwa kehamilan dan persalinan di wilayah kerja bidan kelurahan. Keadaan ini berkaitan dengan rendahnya kepedulian masyarakat untuk kunjungan antenatal, rendahnya ketrampilan dan kemampuan bidan desa, dan manajemen sistem informasi yang belum tersedia.

Dari permasalahan ini, dirancangan sebuah kegiatan berupa KKN PPM. KKN PPM merupakan media pengabdian masyarakat dari dosen bersama mahasiswa dengan pendekatan kerjasama (working with community) dengan masyarakat yang menjadi kelompok sasaran KKN. Dalam KKN PPM ini, universitas bertindak sebagai sumber motivasi, inisiasi, inovasi dan keterampilan teknik kelompok keluarga PUS (Pasangan Usia Subur), ibu hamil, dan bidan kelurahan di Kecamatan Tamalanrea, Kota Makassar.

Tujuan KKN PPM ini adalah untuk meningkatkan pelaksanaan sistem surveilans KIA Puskesmas dalam mengidentifikasi, melaporkan dan mencatat seluruh kejadian kelahiran bayi dari ibu hamil di fasilitas pelayanan kesehatan dan keluarga. Target KKN PPM ini adalah untuk meningkatkan cakupan pencatatan dan pelaporan peristiwa kehamilan dan persalinan di wilayah kerja Kecamatan Tamalanrea, Kota Makassar khususnya di Kelurahan Tamalanrea Jaya.

\section{Metode}

Secara khusus potensi kehamilan dan kelahiran diarahkan kepada keluarga PUS yang mempunyai ibu hamil atau ibu bersalin. Sasaran surveilans ditujukan kepada seluruh peristiwa kelahiran bayi dari seluruh kehamilan yang tercatat. Sehingga metode dan/atau strategi yang dilakukan untuk mencapai kondisi yang diharapkan yaitu Surveilans dan Community development. Tahapan-tahapan pelaksanaan Pengabdian:

1. Sosialisasi ke tokoh masyarakat, bidan kelurahan, petugas Puskesmas, petugas pencatatan kependudukan, dan pengurus LPM kelurahan untuk mendapatkan input tentang masalah surveilans kehamilan dan kelahiran di Kelurahan Tamalanrea Jaya.

2. Pengumpulan dan analisis data sekunder dari Kantor Kecamatan Tamalanea, Rencana Pembangunan masing-masing kelurahan, sistem pencatatan kependudukan Dinas, keadaan indikator kesehatan di Dinas Kesehatan Kota dan Puskesmas, keberadaan dan masalah bidan kelurahan.

Berdasarkan pada hal yang telah dikemukakan diatas, maka tim meyakini perlu upaya untuk memberdayakan potensi keluarga, bidan kelurahan dan LPM untuk menangani masalah yang dihadapi sistem surveilans kehamilan dan kelahiran.

\section{Hasil Dan Pembahasan}

Hasil dan pembahasan penelitian didapatkan dengan metode sensus kesehatan, pelatihan, konsultasi, dan pendidikan masyarakat.

\section{a. Survei Kelahiran Bayi dan Ibu Hamil}

Kegiatan ini dilakukan dengan maksud dan tujuan untuk memperoleh data kelahiran bayi 1 tahun terakhir dan mengidentifikasi ibu hamil.

Hasil Yang Dicapai:

- Telah diperoleh sekitar 111 bayi yang lahir dalam 1 tahun terakhir dan 28 orang ibu yang sedang hamil.

Tindak Lanjut:

- Menginputkan ke system informasi pendataan.

Faktor pendukung:

- Adanya koordinasi yang baik dengan 
Ansari Saleh Ahmar, M.Nadjib Bustan, Ramli Umar. Peningkatan Pemahaman Masyarakat terkait Kelahiran Bayi dan Kependudukan di Kelurahan Tamalanrea Jaya Kecamatan

Tamalanrea Kota Makassar

Puskesmas.

Faktor penghambat:

- Lokasi KKN-PPM yang berada di Lokasi Perumahan Dosen sehingga data hasil survey bisa jadi tidak bisa $100 \%$.

\section{b. Pembuatan Peta Batas RW Kelurahan Tamalanrea Jaya}

Kegiatan ini dilakukan dengan maksud dan tujuan untuk memperoleh data terbaru mengenai batas-batas RW di Kelurahan Tamalanrea Jaya.

Hasil Yang Dicapai:

- Terbentuknya peta administrasi wilayah dan peta infrastruktur di Kelurahan Tamalanrea Jaya.

Faktor pendukung:

- Adanya koordinasi yang baik dengan Pemerintah Kelurahan (Lurah dan Ketua $\mathrm{RW})$.
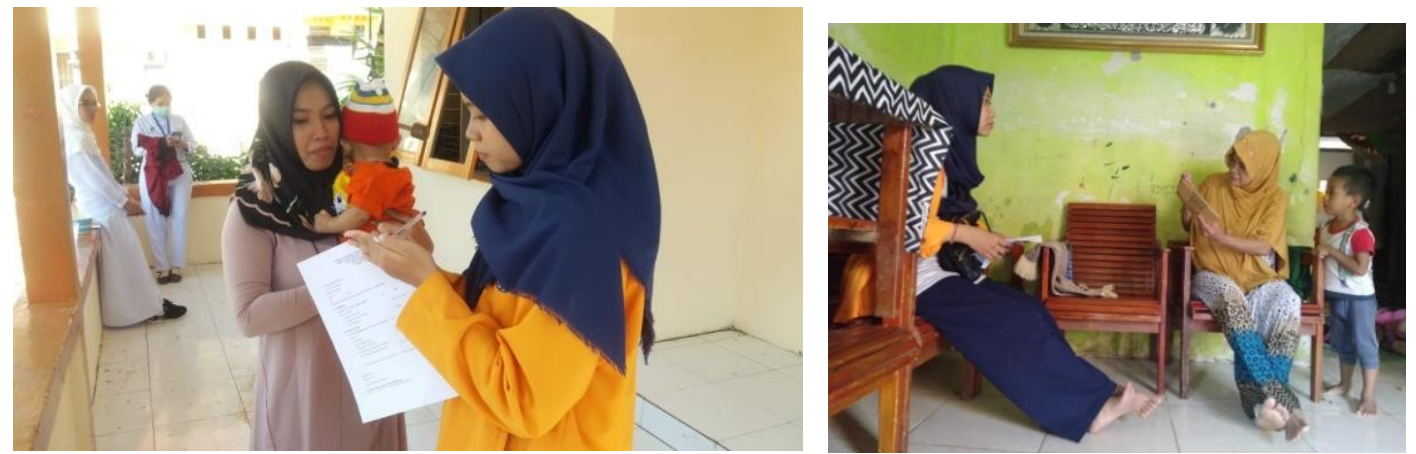

Gambar 1. Survei Kelahiran Bayi, Ibu Hamil, dan Updating Data Kependudukan
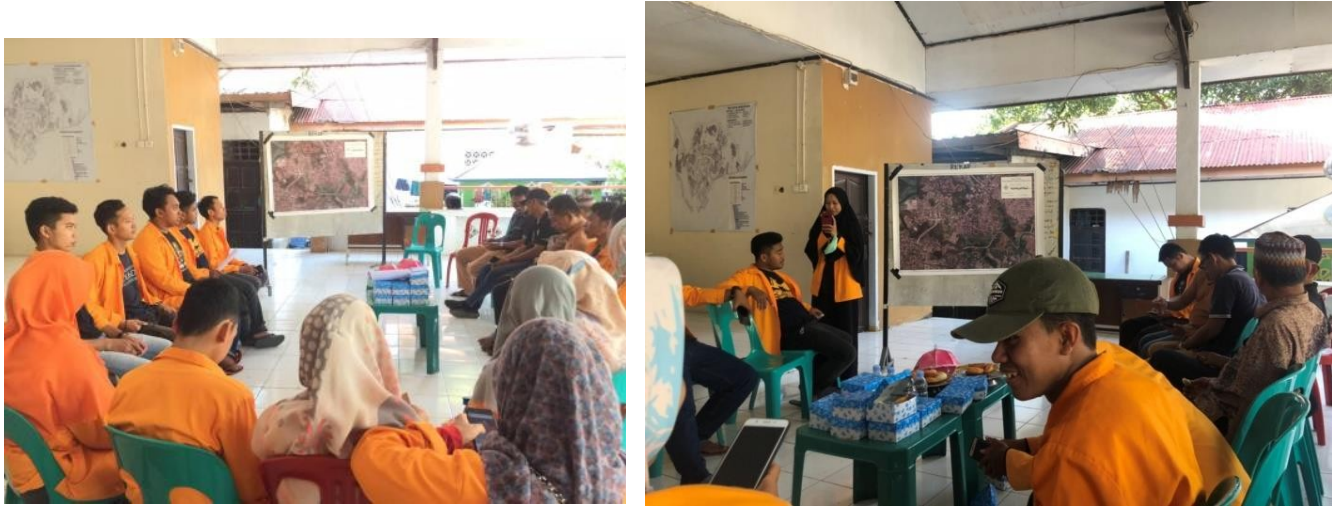

Gambar 2. Diskusi Mengenai Pembuatan Peta Batas RW Kelurahan Tamalanrea Jaya

\section{Simpulan Dan Saran}

Berdasarkan capaian hasil pelaksanaan KKN PPM, dapat disimpulkan sebagai berikut:

1. Meningkatnya partisipasi masyarakat dalam melaporkan diri ketika hamil dan updating data kependudukan

2. Meningkatnya pengetahuan dan keterampilan masyarakat mengenai kelahiran bayi, ibu hamil, dan kependudukan. 
Ansari Saleh Ahmar, M.Nadjib Bustan, Ramli Umar. Peningkatan Pemahaman Masyarakat terkait Kelahiran Bayi dan Kependudukan di Kelurahan Tamalanrea Jaya Kecamatan

Tamalanrea Kota Makassar

\section{Daftar Rujukan}

[1] BPS Kota Makassar. 2019. Kecamatan Tamalanrea dalam Angka 2018.

[2] Kota Makassar. n.d. Geografis Kota Makassar, retrieved from. https://makassarkota.go.id/geografis L

[3] Kota Makassar. 2018. Profil Kota

Makassar 2017. Retrieved from. https://opendata.makassar.go.id/data set/6e87bb86-ab9d-466f-9ac03b5aad960b56/resource/420410a1c1e2-409c-ab4f435ala1ab186/download/profil-kotamakassar-tahun-2017.pdf

[4] Kelana, Aries. 2018. Buku KIA Belum Dimanfaatkan Secara Maksimal. Retrieved from https://www.gatra.com/detail/news/ 346665-Buku-KIA-BelumDimanfaatkan-Secara-Maksimal

[5] Bustan, M. N., Aidid, M. K., \& Sudarmin, S. (2018, November). Ketersediaan Data Kependudukan: Studi Kasus Akta Kelahiran Dan Ktp Elektronik. In Seminar Nasional Variansi (Venue Artikulasi-Riset, Inovasi, Resonansi-Teori, dan Aplikasi Statistika) (Vol. 2018, pp. 175-184). 